\title{
O documentário e seu público
}

\section{Teresa Noll Trindade}

\section{Resumo:}

O crescimento da produção e a valorização do documentário nacional é algo bastante reconhecido nos dias de hoje e os motivos para isso são múltiplos. Porém, a "euforia" por essa conquista pode fazer esquecer um lado dessa história que é referente ao baixo número de espectadores que esses filmes atraem. Pode-se argumentar que esta não é uma questão exclusiva do documentário, mas do cinema nacional como um todo. Este artigo se propõe a analisar este tema: o documentário e seu público. A dinâmica do texto consiste em abordar o problema através de dados estatísticos, realizando uma classificação temática do documentário e discutindo em que medida podemos relacionar a variação de público com a escolha de determinados assuntos.

\section{Palavras Chave:}

Documentário, público e sala de cinema

\begin{abstract}
:
The growth in the production and promotion of national documentary is something quite acknowledgeable today and the reasons for that are manifold. But this "euphoria" sometimes hides the fact that it is a low number of viewers that these movies attract. We can argue that this is not only a documentary matter, but something that happens also in Brazilian cinema as a whole. This article intends to examine exactly such theme: documentary and its audience. The dynamics of the text is to address this problem through statistical data, conducting a thematic classification of the film and discussing to what extent we can relate the change of audience according to the choice of certain subjects.
\end{abstract}

\section{Keywords:}

Documentary, audience and movie theather

O crescimento da produção e a valorização do documentário nacional nos últimos anos são indiscutíveis e as razões para estes fatos são múltiplas. Uma hipótese possível é o que podemos chamar de "efeito Michael Moore"; um imenso público é levado ao cinema por causa do referido diretor, que aborda temas polêmicos e esta dinâmica pode ter contribuído para o crescente interesse no cinema documental. Paralelamente a isso, mudanças estruturais favoreceram o aumento da produção nacional desse tipo de filme, dentre as quais podemos citar: o barateamento dos custos de produção, distribuição e exibição, relacionadas com a tecnologia digital; a criação e proliferação de festivais e editais de financiamento para a área. Ao lado desses elementos, houve também um crescimento da produção intelectual e da crítica em torno do documentário, envolvendo desde publicações destinadas a este tipo de filme até a criação de cursos de graduação e de pós-graduação.

O ano de 2004 foi marcado, segundo Amir Labaki, pelo "boom do documentário", pois houve o lançamento de 16 filmes em circuito comercial de cinema, cifra essa que, comparada com os cinco lançamentos do ano anterior, representa um incremento quantitativo substancial (isto se torna mais importante quando além destes números percebemos um considerável aumento qualitativo das produções). 
Os anos seguintes mostrarão ser esta uma tendência permanente de crescimento. Porém, é importante ressaltar que este "boom" não necessariamente fez com que todos os documentários chegassem ao cinema e, mesmo aqueles que chegaram, nem todos tiveram uma resposta positiva de bilheteria, pois foram raros os documentários que alcançaram a marca de 50 mil espectadores. Mesmo estes, ficaram restritos às capitais culturais (São Paulo, Rio, Belo Horizonte, Porto Alegre, Brasília) (1). Ainda assim, a partir de 2004, segundo Consuelo Lins, estas boas bilheterias têm se tornado mais freqüentes: "Embora o documentário tenha correspondido, em 2007, ao segundo "gênero" com maior número de lançamentos no mercado brasileiro (posicionando-se depois do "drama" e superando "comédia", "animação", "aventura" e "ação"), os filmes brasileiros são lançados de modo tímido e restrito. Mas as exceções se multiplicam"(2). Esse interesse pelo documentário não se restringe só ao Brasil, mas a outros países como Estados Unidos e França.

A exibição de filmes brasileiros em salas de cinema não é um problema restrito ao campo do documentário. Pelo contrário, a ficção sofre, embora em doses um pouco menores, do mesmo mal - sem querer entrar, aqui, em outra questão que é o valor elevado das entradas de cinema. O questão do número reduzido de espectadores que freqüentam salas exibindo filmes nacionais não é um problema novo. O que talvez venha agravando essa situação é a proliferação do modelo Multiplex - complexo de salas de cinema - que exibem, em sua maioria, filmes americanos (3). O que parece ser destinado ao cinema brasileiro é o acesso a poucas salas desse "complexo", nos horários comercialmente pouco nobres e com reduzidíssima permanência em cartaz. O padrão mais comum é o da entrada direta dos filmes nos circuitos alternativos onde há a possibilidade de exibição em horários de maior público e permanência maior.

Outro elemento essencial para compreender o momento que atravessa o documentário no Brasil é a tecnologia digital. Com ela, barateou-se o custo de produção, distribuição e também de exibição. Neste ponto é importante constatar que o considerável aumento da produção brasileira não foi acompanhado, com o mesmo vigor, pelo sistema exibidor (embora tenha havido uma abertura de espaço para documentários, o número de salas de exibição se manteve praticamente o mesmo). Isto ocorre, grosso modo, por não se ter conseguido constituir nenhum tipo de estratégia/mecanismo que proporcionasse, juntamente com o crescimento da produção, um similar efeito no sistema distribuidor e consequientemente no exibidor, levando o documentário a buscar as salas de cinema, para muitos local exclusivo da ficção. No Brasil ainda não há um espaço para o documentário na televisão, como outros países, onde ela é o veiculo "natural" desse tipo de produção, existindo, inclusive, canais especializados (4) . O cinema documentário, assim como a ficção vem buscando criar um mercado para exibição dos seus filmes.

Buscarei, neste trabalho, realizar uma classificação por temática de alguns documentários que estão presentes nessa produção contemporânea para, dessa forma, realizar uma análise a partir de dados estatísticos. Embora possamos admitir que isso seja algo reducionista, pois dessa forma estou "forçando" alguns filmes a se enquadrarem numa tipificação preestabelecida, acreditamos que, ainda assim, podemos trazer contribuições e reflexões sobre o documentário e seu público.

\section{Classificação dos documentários em grupos temáticos}

Busquei, para o propósito deste texto, agrupar em seis grupos temáticos a produção documentária realizada dentro do período de 1996 a 2006 e exibida comercialmente em cinema, com o objetivo de poder analisar os dados(5) estatísticos obtidos e com o fim de lançar alguns questionamentos, bem como de cruzar dados que poderão nos conduzir a conclusões interessantes. Os grupos temáticos que estabeleci são: 1- documentários de personagem, 2- documentários sobre questões sociais, 3- documentários sobre personalidades, 4- documentários com mote esportivo 5- documentários com mote musical e, 6documentários de aprofundamento temático. A categorização desses filmes documentários acaba por reduzi-los, temática e esteticamente, já que na medida em que os classificamos, estabelecemos que há um 
núcleo temático determinante tomado como referência para o enquadramento. Como se trata de um trabalho experimental, a classificação de alguns filmes em certas categorias poderá ser repensada. O objetivo que nos move, entretanto, justifica essa démarche que pode esclarecer certos pontos de produção bem como a aproximação que essas temáticas têm com o público.

\section{a) Documentários de Personagem ou Personagens}

São filmes que constroem sua narrativa nos depoimentos de pessoas que, em sua maioria, contam sobre suas vidas, cotidiano, manias, problemas, traumas. Essa história pode ser contada através de depoimentos de mais de uma pessoa. Os filmes enquadrados nessa categoria que eu nomeio de documentário de personagem, em sua maioria, apresentam pessoas desconhecidas previamente ao filme. São exemplos de documentários nessa categoria: Edifício Master, Santo Forte, Peões, Babilônia, O fim e o princípio, Estamira, A pessoa é para o que nasce, 33, Fala tu, Morro da Conceição, O chamado de Deus, Meninas, Nem gravata nem honra e Vocação do poder.

Um diretor que pode ter quase toda a sua produção nessa categoria é Eduardo Coutinho, na medida em que todos os seus filmes apresentam pessoas desconhecidas que falam para e com o diretor, e este, na maioria das vezes, aparece no enquadramento e acaba tornando-se personagem do próprio filme. No filme 33, de Kiko Goifman, há também a presença do diretor como personagem, já que ele relata sua busca pela mãe biológica. Há em 33 o uso de atores também, mas acredito que dentro das categorias criadas, ele encontra melhor classificação neste item. O filme de Marcos Prado, Estamira, conta a história desta mulher, esquizofrênica, que revela ao espectador sua lógica de mundo, em meio à trágica realidade em que vive. O documentário A pessoa é para o que nasce, narra a história de três irmãs cegas que vivem da música, cantando na rua. $\mathrm{O}$ diretor acompanha essa rotina e também aparece no enquadramento em alguns momentos, assim como a sua voz. Fala tu, segue a vida de três moradores da Zona norte do Rio de Janeiro que têm em comum a paixão pela música. Fala tu não foi encaixado na categoria de Documentário de Mote especificamente musical pois julgo que a música não é o cerne deste filme e, sim, a vida desses três personagens. Morro da Conceição filma oito moradores idosos que habitam o Morro da Conceição e que narram suas vidas. $O$ chamado de Deus aborda o tema da religião através de seis jovens que optaram por entrar no seminário. O filme Meninas acompanha a gravidez de meninas adolescentes provenientes das classes de baixa renda. Em Nem gravata nem honra, Marcelo Mazagão filma a vida de homens e mulheres da cidade de Cunha, onde vai analisar as diferenças entre o sexo feminino e o masculino e, finalmente, Eduardo Escorel seguirá seus personagens no período eleitoral, quando estes concorrem a uma cadeira de vereador pela primeira vez, em Vocação do poder.

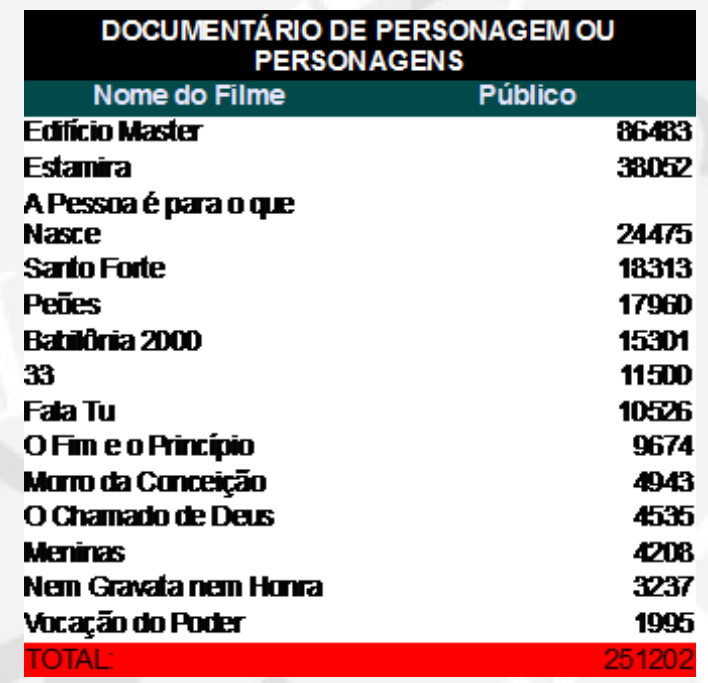




\section{DOCUMENTARIO DE PERSONAGE OU PERSONAGENS}

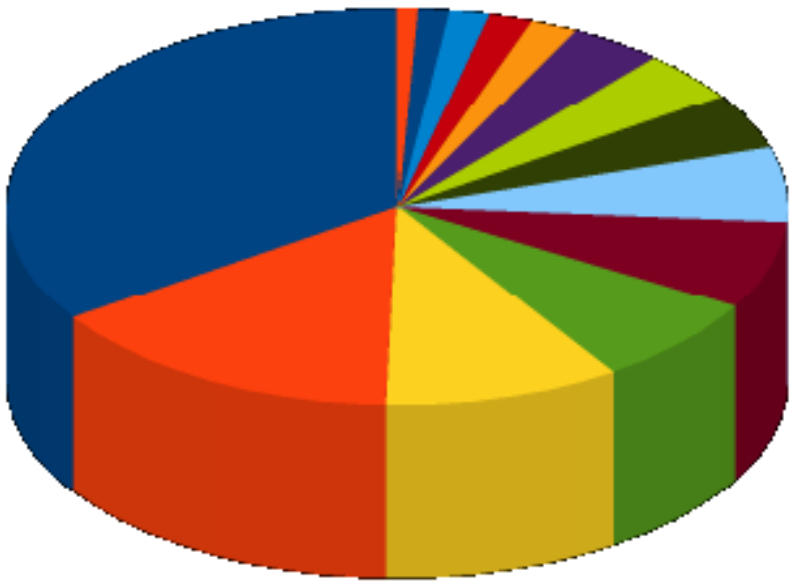

Edifício M aster

Estamira

A Pessoa é para o $q$

- Santo Forte

- Peões

Babilônia 2000

口 33

Fala Tu

口 Fim e o Principio

Morro da Conceição

- 0 Cham ado de Deu

Meninas

- Nem Gravata nem $\mathrm{H}$

- Vocação do Poder

\section{b) Documentários sobre Questões Sociais}

Os filmes que tratam de questões sociais, questões ainda carentes de solução no Brasil, em alguns casos se configuram como filmes de denúncia. Enquadramos, também, nesta categoria, a produção recorrente de documentários sobre a ditadura militar brasileira, realizados em sua maioria por diretores que viveram este período da história política. São exemplos da categoria: Ônibus 174, Justiça, Prisioneiro da grade de ferro, $O$ rap do pequeno príncipe, $O$ sonho de Rose, $O$ sol - Caminhando contra o vento, $O$ cárcere e a rua, Barra 68, A margem da imagem, Dia de festa, O dia em que o Brasil esteve aqui, Zé Pureza, Família Alcântara e Preto e branco. Os filmes que tratam sobre o período da ditadura são: $O$ sol - Caminhando contra o vento e Barra 68. Os documentários Ônibus 174, Justiça, Prisioneiro da grade de ferro, O rap do pequeno príncipe, $O$ cárcere e a rua, $O$ dia em que o Brasil esteve aqui, Família Alcântara e Preto $e$ branco, são filmes que apresentam, em sua maioria, problemas como a pobreza, a violência, prisões superlotadas, corrupção policial, justiça brasileira e questões do racismo estrutural brasileiro. Já os filmes, A margem da imagem e Dia de festa, tratam sobre os moradores de rua da cidade de São Paulo, e poderiam se encaixar no modelo de documentário de aprofundamento temático, mas como existe um recorte social muito grande, julguei que se enquadrariam melhor aqui. Os filmes que retratam a vida de seus personagens, mas estes fazendo parte de movimentos sociais específicos, são: $O$ sonho de Rose e Zé Pureza. Ambos são sobre a questão agrária no Brasil e apresentados através da vida de Zé Pureza e Rose. Eles também poderiam se enquadrar no modelo de documentário de personagem mas, como dito anteriormente, o recorte social é mais relevante nessas obras.

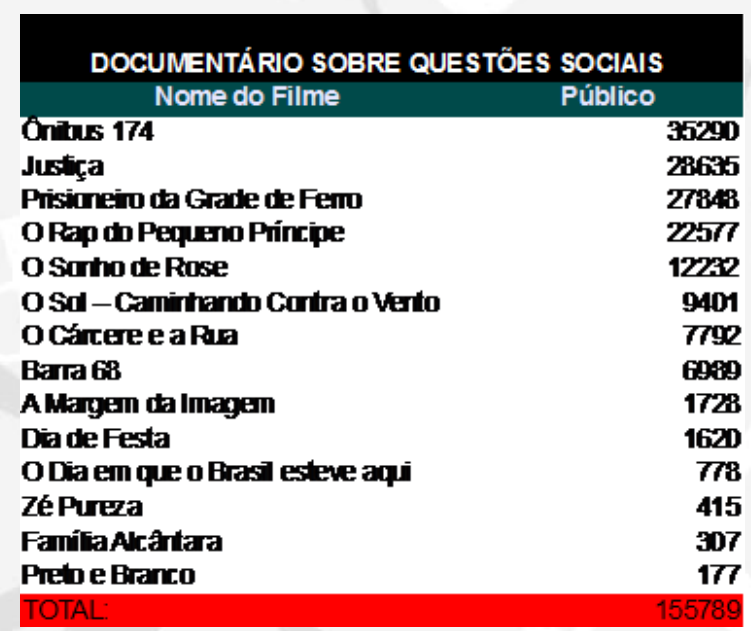



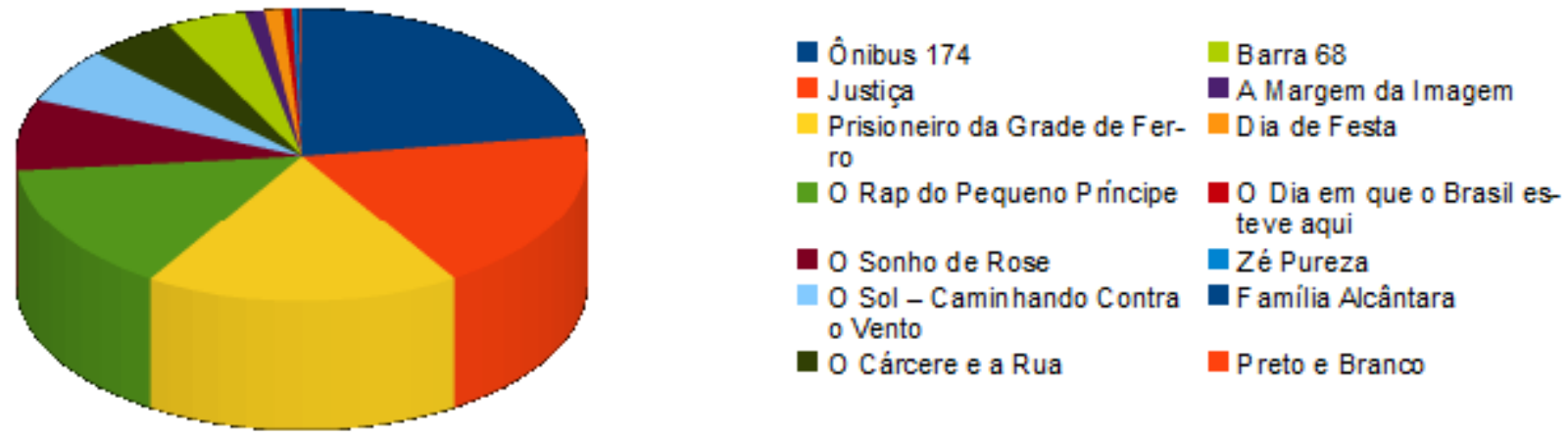

\section{c) Documentários de Personalidades}

São filmes que podem ou não utilizar o recurso da entrevista como fio condutor da narrativa fílmica, mas que fazem isso para contar a história de pessoas que são conhecidas em seu meio profissional e que, em alguns casos, são conhecidas do grande publico que vai ao cinema. São exemplos dessa categoria os filmes: Vinícius (sobre o poeta, compositor e escritor Vinícius de Morais), Entreatos (campanha presidencial de Luiz Inácio da Silva, Lula, em 2002), Gláuber - o filme (sobre a vida de Gláuber Rocha, cineasta do Cinema Novo), O velho - Historia de L.C. Prestes (história de Luis Carlos Prestes, líder comunista), Rio de Jano (história do desenhista francês Jano), Rocha que voa (também sobre Gláuber Rocha), O cineasta da selva (sobre o cineasta Silvino Santos), Poeta das sete faces (vida de Carlos Drummond de Andrade), Onde a terra acaba (história do cineasta Mario Peixoto), Dom Helder Câmara (história do bispo católico Dom Helder Câmara), Pierre Verger (história do fotógrafo e etnógrafo francês Pierre Verger), Vlado - 30 anos depois (trágica história de Vladimir Herzog, jornalista assassinado pelo Dops), Moacir arte bruta (história do pintor e desenhista Moacir), A mochila do mascate (sobre a vida e arte do cenógrafo Gianni Ratto), O homem pode voar (sobre Alberto Santos Dumont), Anésia - Um vôo no tempo (história de Anésia Pinheiro Machado e sua relação com a aviação), Evandro Teixeira Instantâneos (vida e obra do fotojornalista Evandro Teixeira).

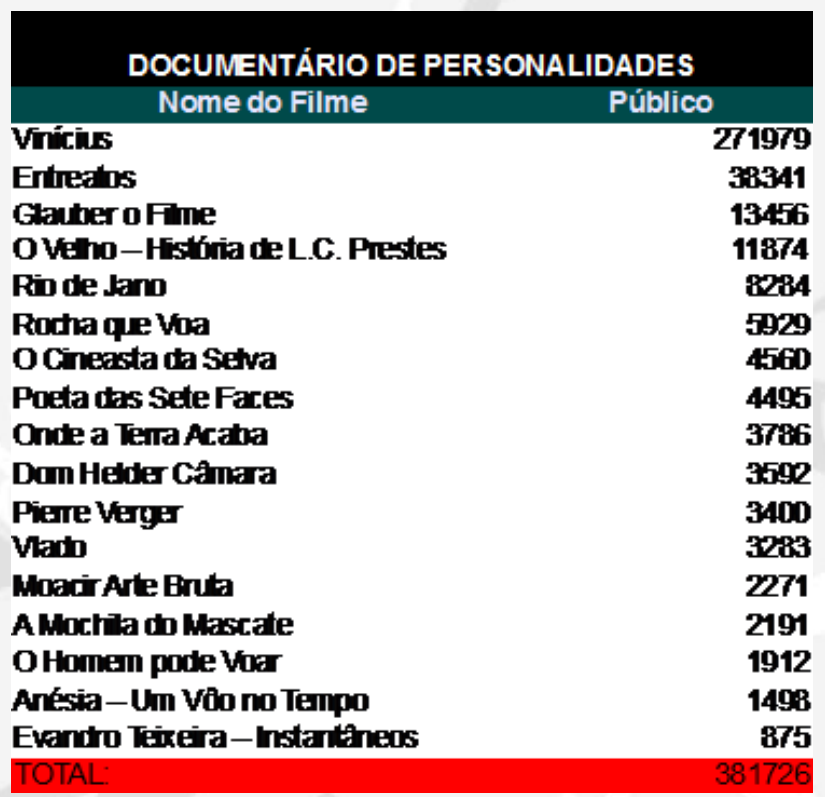


DOCUMENTÁRIO DE PERSONALIDADES
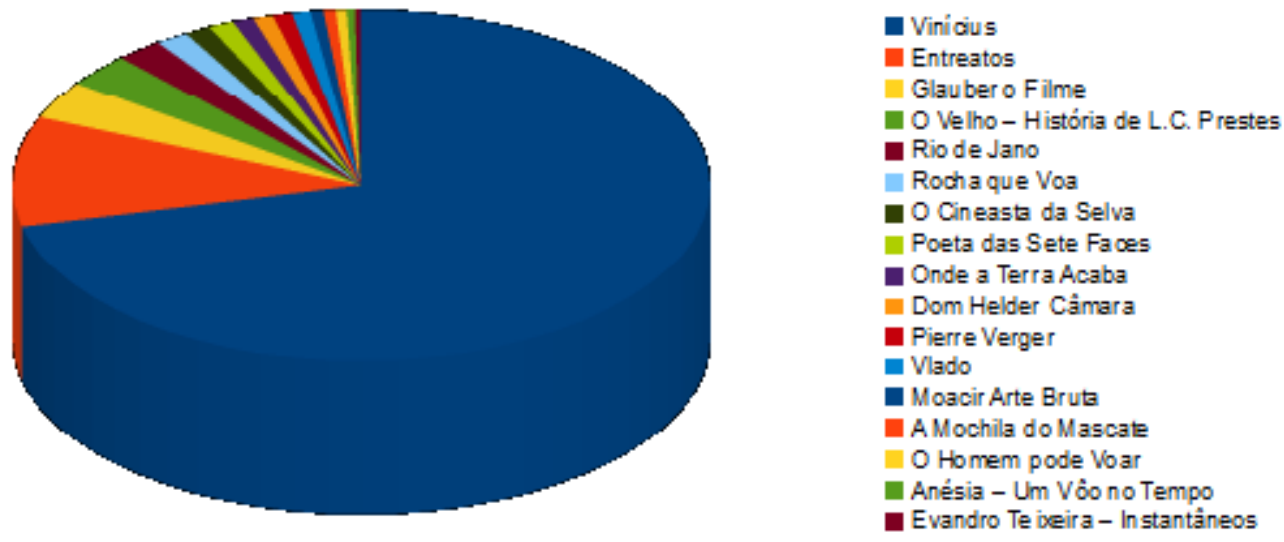

\section{d) Documentários com Mote Esportivo}

São documentários que apresentam a temática do esporte como premissa básica. Em alguns casos são filmes de celebridades do esporte. São exemplos dessa categoria: Todos os corações do Mundo, Histórias do Flamengo e Ginga(sobre o futebol), Pelé eterno, Um craque chamado divino e Zico, os três sobre celebridades do futebol, Surf Adventures, Fábio Fabuloso e Town-in surfing, são filmes que tratam do esporte surf e no caso de Fábio Fabuloso, de um surfista específico e Extremo sul sobre alpinismo.

Pelé eterno, Um craque chamado divino e Zico, são sobre a vida de celebridades do futebol brasileiro e poderiam também ser enquadrados no modelo de documentário de personalidades, mas estão nesta categoria por serem personalidades do esporte, onde a ênfase está nesta particularidade. Extremo sul retrata a tentativa de um grupo de alpinistas brasileiros e argentinos de escalar o Monte Sarmiento, fato que não ocorre, fazendo com que este filme pudesse ser encaixado no modelo de Documentários de Personalidade, ou, até mesmo, de Personagem. Porém, como o tema principal é a tentativa dos alpinistas subirem a montanha, cremos que ele se enquadra bem nesta categoria.

\begin{tabular}{|c|c|}
\hline \multicolumn{2}{|c|}{ DOCUMENTÁRIO COM MOTE ESPORTIVO } \\
\hline Nome do Filme & Público \\
\hline Todos os Coraçōes do Mundo & 265017 \\
\hline Pelé Etemo & 257932 \\
\hline SufAdveritures & 200853 \\
\hline Extiemo Su & 13571 \\
\hline Fäbio Fabuloso & 12458 \\
\hline Histónias do Pamengo & 11157 \\
\hline Tom-in Surfing & 2398 \\
\hline Ginga & 1265 \\
\hline UmCraque Chamado Divino & 1148 \\
\hline Zico & 1000 \\
\hline TOTAL & 76680 \\
\hline
\end{tabular}




\title{
DOCUMENTÁRIO COM MOTE ESPORTIVO
}

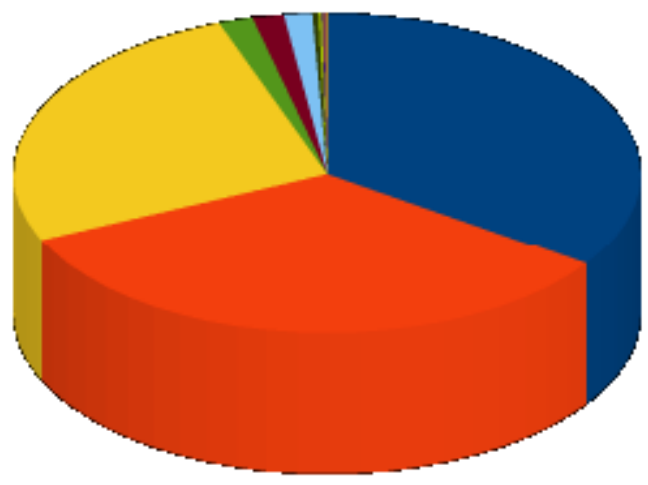

\author{
- Todos os Coraçôes do Mundo \\ - Pelé Etemo \\ Surf Adventures \\ Extremo Sul \\ - Fábio Fabuloso \\ Histórias do Flamengo \\ - Town-in Surfing \\ Ginga \\ U U Craque Cham ado Divino \\ Zico
}

e) Documentários com Mote Especificamente Musical

São filmes que tratam da temática música brasileira, e em alguns casos de celebridades desse setor. São exemplos dessa categoria: Nelson Freire, Paulinho da Viola, Um certo Dorival Caymmi e Nelson Gonçalves, todos de personalidades da música brasileira. Já os filmes: Coisa mais linda, Viva São João, Carnaval, Bexiga, Funk e sombrinha, Sou feia mais To na Moda, Moro no Brasil, Banda de Ipanema, Samba Riachão, Bahia de Todos do Sambas e Nizinga, abordam a questão mais da música em si do que personalidades específicas.

\begin{tabular}{|c|c|}
\hline \multicolumn{2}{|c|}{$\begin{array}{c}\text { DOCUMENTÁRIO COM MOTE ESPECIFICAMENTE } \\
\text { MUSICAL }\end{array}$} \\
\hline Nome do Filme & Público \\
\hline NeksonFrite & 6426 \\
\hline Pailino da Viala & 54008 \\
\hline Coisa Mass Linda & 35961 \\
\hline VMa Sā̃ Joāo & 70 \\
\hline Camaal, Bexiga, Fuk e Sombinha & 695 \\
\hline Sou Feia mas Tô na Hoda & करा \\
\hline Nexsm Gurcalues & 439 \\
\hline Moro no Brast & $\mathbf{2 6}$ \\
\hline Um Ceto Duival Caymmi & $\mathbf{2 0}$ \\
\hline Banda de Ipanema & $\mathbf{2 0 0 4}$ \\
\hline Sanha Riarhān & 13 \\
\hline Batia de Todos os Samhas & 10 \\
\hline Nizinga & 21 \\
\hline
\end{tabular}




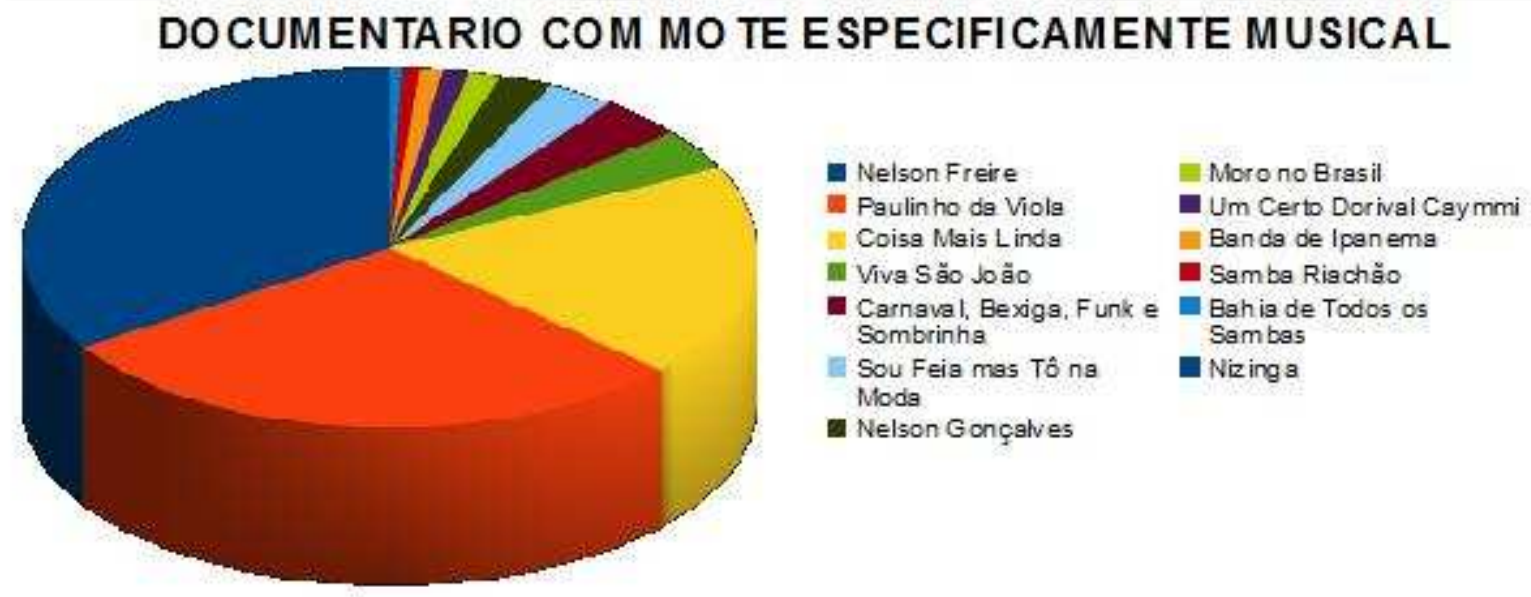

f) Documentários de Aprofundamento Temático

Essa categoria reúne filmes que de alguma forma tratam de assuntos específicos e que podem ou não fazer uso da entrevista e geralmente utilizam vários relatos na medida em que contribuem para a análise de determinado assunto. São exemplos dessa categoria os filmes: Janela da alma, Nós que Aqui estamos por Vós Esperamos, Doutores da Alegria,Raízes do Brasil, Soy Cuba - o mamute siberiano, Senta a Pua, Língua - Vidas em Português, Passaporte Húngaro, Fé, Timor Lorosae - o massacre que o mundo não viu, 2000 Nordestes, Olhar Estrangeiro, Do luto à Luta, Soldado de Deus, Tudo é Brasil, Terra do Mar, Parteiras da Luz.

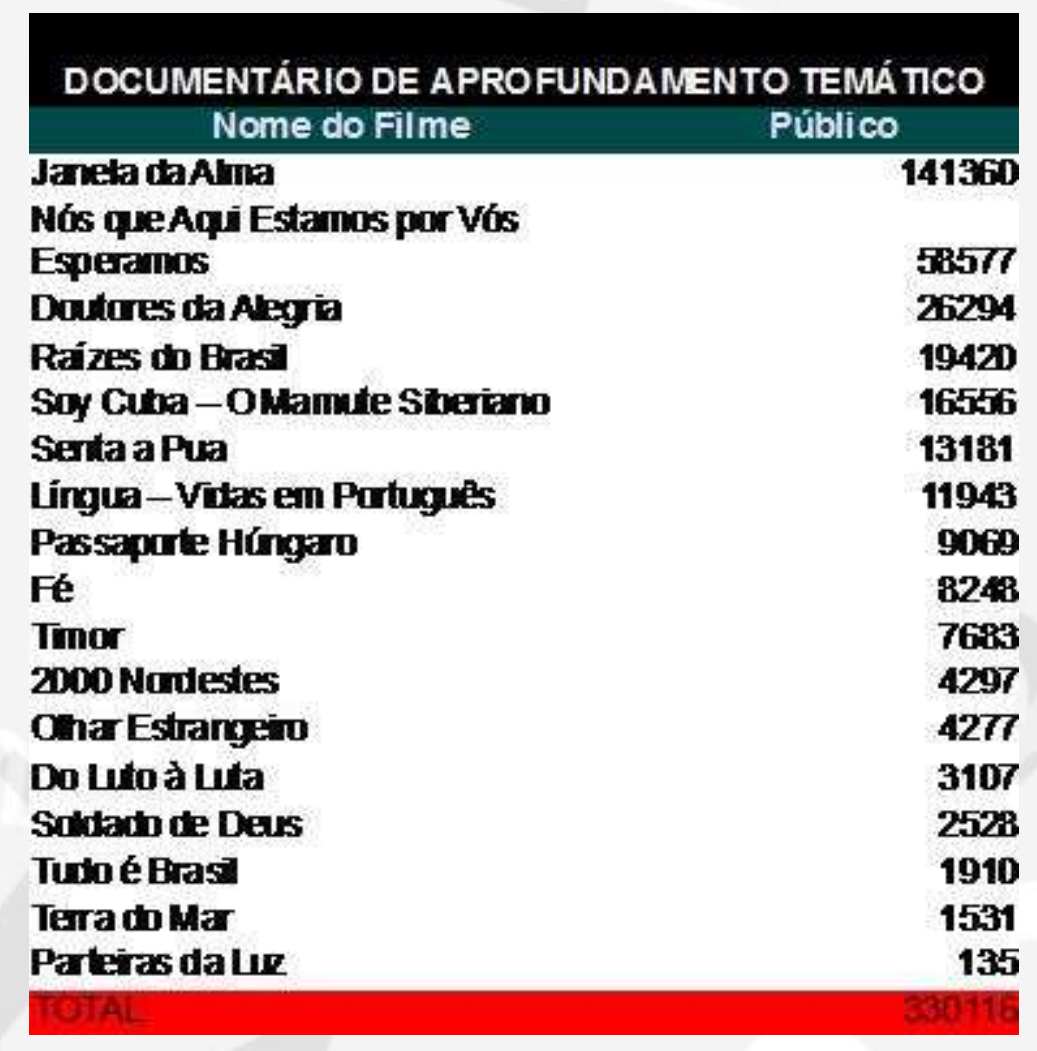




\section{Análise de público por temática}

Através do agrupamento dos filmes em grupos temáticos foi possível fazer uma análise proporcional do público de cada modalidade. Através desses dados podemos observar que a temática que tem trazido mais público ao cinema é: Documentário com Mote esportivo. Aqui vale ressaltar que os três primeiros filmes dessa categoria estão no topo de bilheteria do documentário nacional, só perdendo para Vinícius (Personalidade). Os três primeiros filmes são responsáveis por um total de público de 723.802 pessoas. A categoria como um todo apresenta um público de 766.800 .

O grupo temático que está em segundo lugar em número total de espectadores arrecadados é o Documentário de Personalidades, no qual em há um total de público de 381.726. Nesse grupo, encontra-se o filme de maior bilheteria do documentário nos últimos anos que é Vinícius. Este, sozinho, arrecadou um público de 271.979, o que representa mais da metade do total de público dessa categoria.

Em terceiro lugar, está o grupo de Documentário de Aprofundamento Temático. Este arrecadou um total de 330.116 espectadores, mas conta com o quinto e o oitavo filmes tops de bilheteria que são Janela da Alma (141.360) e Nós que Aqui estamos por Vós esperamos (58.577). O público dos dois juntos representa um total de 199.937, sendo um total que é superior à metade do total da categoria que é de 330.116.

O grupo que está em quarto lugar, em termos de público, é o de Documentário de Personagem. O total de público dessa categoria é de 251.202. Deste setor faz parte o diretor Eduardo Coutinho, que é o diretor que tem mais filmes documentários lançados comercialmente. É, interessante, inclusive, observar que no topo da bilheteria se encontra um filme seu - Edifício Master - que reuniu um público de 86.483. Este documentário foge do padrão de bilheteria que seus filmes arrecadam, já que estes ficam numa média de 17 mil espectadores, que é o que arrecadaram Santo Forte, Peões e Babilonia 2000.

Depois, temos a categoria que está em quinto lugar: Documentário com Mote Especificamente Musical. Nesse grupo pode-se observar que os dois primeiros filmes tops de bilheteria Nelson Freire (64.264) e Paulinho da Viola (54.025) representam um total de 118.289, o que constitui mais da metade do total deste grupo de filmes que é 187.301.

E, em último lugar no ranking de bilheteria se encontra o grupo de Documentário sobre Questões Sociais, representando um público total de 155.789. Dentro dessa categoria há três filmes que representam a metade do total de público do grupo todo. São eles: Ônibus 174 (35.290), Justiça (28.635) e Prisioneiro da Grade de Ferro (27.848). Esses filmes representam um total de 91.773 espectadores, sendo que o total do grupo é de 115.789.

Observando essas categorias e seus públicos é possível perceber que não existe uma constância de público por temática no documentário brasileiro.

\section{Lançamento por Temática}

É possível analisar, através dos dados, que dois grupos temáticos empatam em número de lançamentos. São eles: Documentários de Personalidades, que teve um total de 17 filmes, e Documentários de Aprofundamento Temático, também com 17 lançamentos. Depois, temos outro empate, entre o grupo Documentário de Personagem e Documentário sobre Questões Sociais, ambos com 14 lançamentos. Segue-se Documentário com Mote Especificamente Musical com 13 lançamentos, e por último

Documentário com Mote Esportivo com 10 lançamentos. É interessante destacar o fato de que o tipo de documentário com menor número de lançamentos é também o tipo que concentra o maior número de 
público que é de 723.802.

\begin{tabular}{|l|c|}
\hline \multicolumn{2}{|c|}{ Total de filmes exibidos por grupo temático } \\
\hline \multicolumn{1}{|c|}{ Grupo Temático } & $\begin{array}{c}\text { Nonçamentos (1996- } \\
2006)\end{array}$ \\
\hline $\begin{array}{l}\text { Documentário de } \\
\text { Personalidade }\end{array}$ & 17 \\
\hline $\begin{array}{l}\text { Documentário de } \\
\text { A profundamento Temático }\end{array}$ & 17 \\
\hline $\begin{array}{l}\text { Documentário de } \\
\text { Personagem }\end{array}$ & 14 \\
\hline $\begin{array}{l}\text { Documentário sobre } \\
\text { Questóes Sociais }\end{array}$ & 14 \\
\hline $\begin{array}{l}\text { Documentário com Mote } \\
\text { Especificamente Musical }\end{array}$ & 13 \\
\hline $\begin{array}{l}\text { Documentário com Mote } \\
\text { Esportivo }\end{array}$ & 10 \\
\hline
\end{tabular}

\begin{tabular}{|l|c|}
\hline \multicolumn{2}{|c|}{ Público Total por Temática } \\
Gublico Total (1996- \\
G006)
\end{tabular}

\section{Público total do documentário de 1996 a 2006 por temática}

Avaliando o público do documentário nacional por temática, podemos concluir que Vinicius, filme encaixado dentro do modelo de filme de Personalidades, é uma exceção de público. Este arrecadou um total de 271.979. Na sequiência do ranking de público há três filmes do modelo de Documentário de Mote Esportivo, que são: Todos os corações do mundo, Pelé eterno e Surf adventures e, nesses casos, podemos considerar isso um movimento linear constante, todos com públicos acima de 200 mil. Logo, pode-se concluir, que existe um interesse de parte do público por temas relacionados, principalmente, ao futebol e ao surf. A exceção é o filme Extremo sul sobre alpinismo.

Já o modelo de Documentários de Personalidades, embora tenha um número de lançamentos grande, relacionando-o com os demais tipos, ele não necessariamente traz público a seus filmes no conjunto, ao contrário, a posição no ranking se deve a alguns casos individuais. Este modelo só está em segundo lugar em público total por temática pelo fato de, nessa categoria, se encontrar o filme Vinicius, que fez a maior 
bilheteria dentro do período analisado.

No modelo temático há um exemplo parecido com o anterior que é o filme Janela da alma. Este é uma exceção já que "carrega" os outros e os coloca em terceiro lugar de público. Nesse exemplo, temos um filme que tem 141 mil espectadores e, em segundo lugar, Nós que aqui estamos por vós esperamos que já tem uma redução para 58 mil, sendo que o terceiro lugar já cai para 26 mil.

O modelo de personagem ou personagens, que está em quarto lugar, é uma categoria que, embora sofra do mesmo problema das demais, ou seja, um ou dois filmes com mais público são responsáveis por significativas bilheterias, ela tende a mostrar um padrão mais equilibrado de público. Nesse caso temos Edifício Master, que fez 86 mil espectadores, que além do primeiro no ranking do modelo, é também o filme de Eduardo Coutinho que fez mais público, sendo interessante ressaltar que todos os seus demais filmes se encaixam nesse modelo. Em segundo lugar está Estamira com 38 mil, uma queda considerável já que é o segundo lugar no ranking.

No modelo musical, semelhante aos demais, temos três filmes que ficam na casa dos 60 a 30 mil e depois os filmes têm uma queda para 7 mil. Não é diferente com o modelo de aprofundamento temático onde temos um filme que fez 140 mil espectadores e, em segundo lugar, um que fez 50 mil e o terceiro lugar já cai para 20 mil.

\begin{tabular}{lr}
\multicolumn{1}{c}{ Tipo } & Público \\
\hline Mote Esportivo & 766800 \\
Personalidades & 381726 \\
Aprofundamento Temático & 330116 \\
Personagem ou personagens & 251202 \\
Mote especificamente Musical & 187301 \\
Questöes sociais & 155789
\end{tabular}

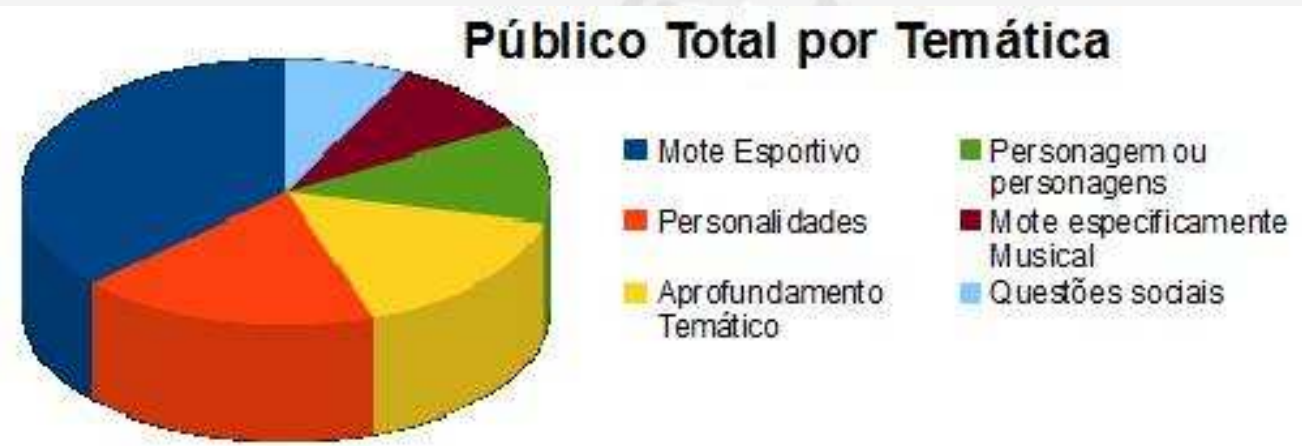




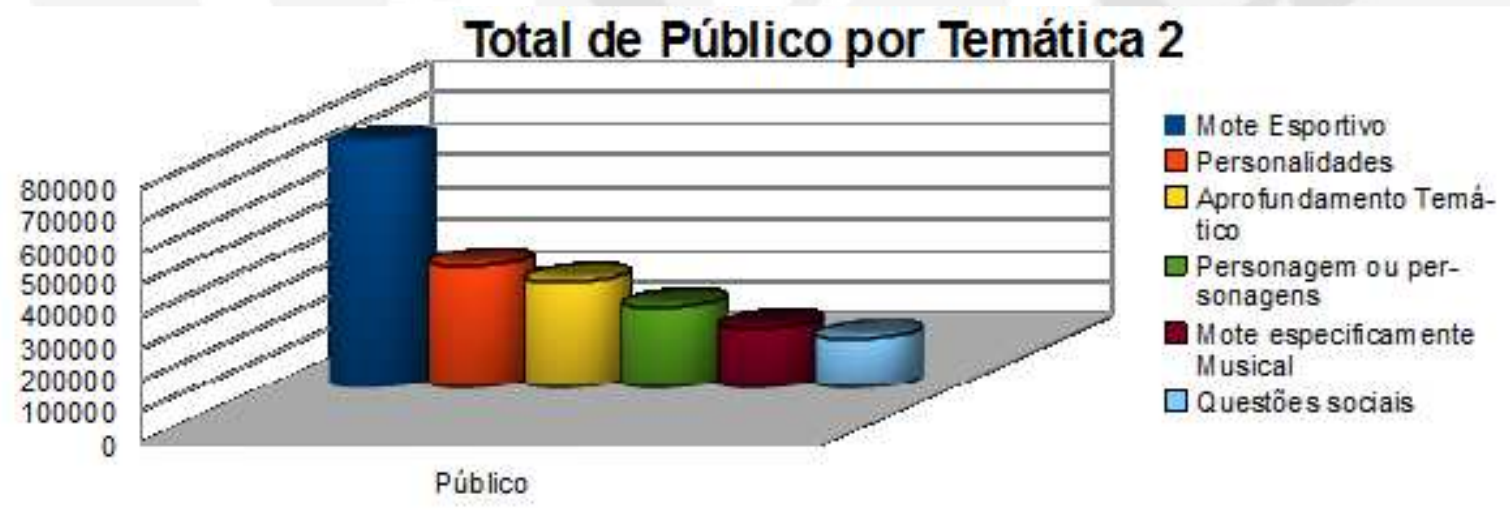

Público do Documentário por Ano

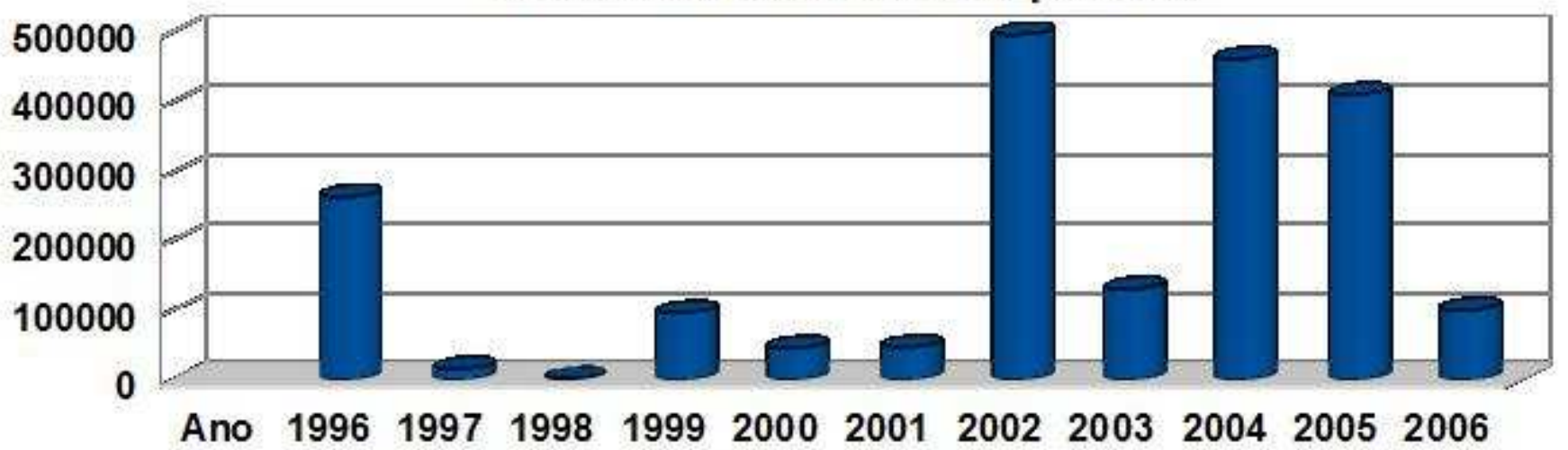

\section{Aumento de lançamentos e diminuição de público}

Se formos observar os gráficos podemos constatar que realmente ocorreu o que Amir Labaki chamou de boom do documentário, 16 lançamentos em 2004, visto que em 2003 o lançamento foi de apenas 5 filmes, e que desde 1996 o maior número de lançamentos havia sido 10 filmes no ano de 2002. Porém, é interessante ressaltar que, com exceção de Vinícius (2006), e Pelé eterno (2004), que estão no primeiro e terceiro lugar no ranking de público do documentário, os demais filmes na seqüência do ranking são anteriores a esse boom de 2004; o segundo lugar Todos os corações do mundo (1996), o quarto lugar Surf Adventures (2002), o quinto lugar Janela da Alma (2002), o sexto lugar Edifício Master (2002), o sétimo lugar Nelson Freire (2003), o oitavo lugar Nós que Aqui Estamos por Vós Esperamos (1999) e o nono lugar Paulinho da Viola (2003). Ou seja, há num conjunto de nove campeões de público, apenas dois posteriores ao chamado boom, os demais são anteriores a 2004.

É também interessante notar que há três filmes exibidos no ano de 2002 e que estão entre os nove primeiros na lista de público, lembrando que no ano de 2002 tivemos apenas dez lançamentos comerciais. Os anos de 2004 e 2005 também têm públicos relevantes, mas isso se deve ao aumento do número de lançamentos, que subiu para quinze. É possível visualizar que, embora tenha ocorrido um boom de lançamentos no ano de 2004, está diminuindo a média de público por filme. 


\begin{tabular}{|c|c|c|c|}
\hline Ano & Número de Documentários Lançados & Total de Püblico & Média de Público por lançamento \\
\hline 1996 & 1 & 265017 & 265017 \\
\hline 2002 & 10 & 496208 & 49620,8 \\
\hline 2004 & 16 & 462236 & 28889,75 \\
\hline 2005 & 15 & 410962 & 27397,47 \\
\hline
\end{tabular}

Análise de dados sem as cinco maiores bilheterias

\begin{tabular}{|cc|}
\hline Ano & Publico \\
\hline 1996 & 0 \\
1997 & 16454 \\
1998 & 1910 \\
1999 & 96295 \\
2000 & 45922 \\
2001 & 47113 \\
2002 & 153995 \\
2003 & 130362 \\
2004 & 204304 \\
2005 & 138983 \\
2006 & 100475 \\
\hline
\end{tabular}

Evolução do público excluindo as $\mathbf{5}$ maiores bilheterias

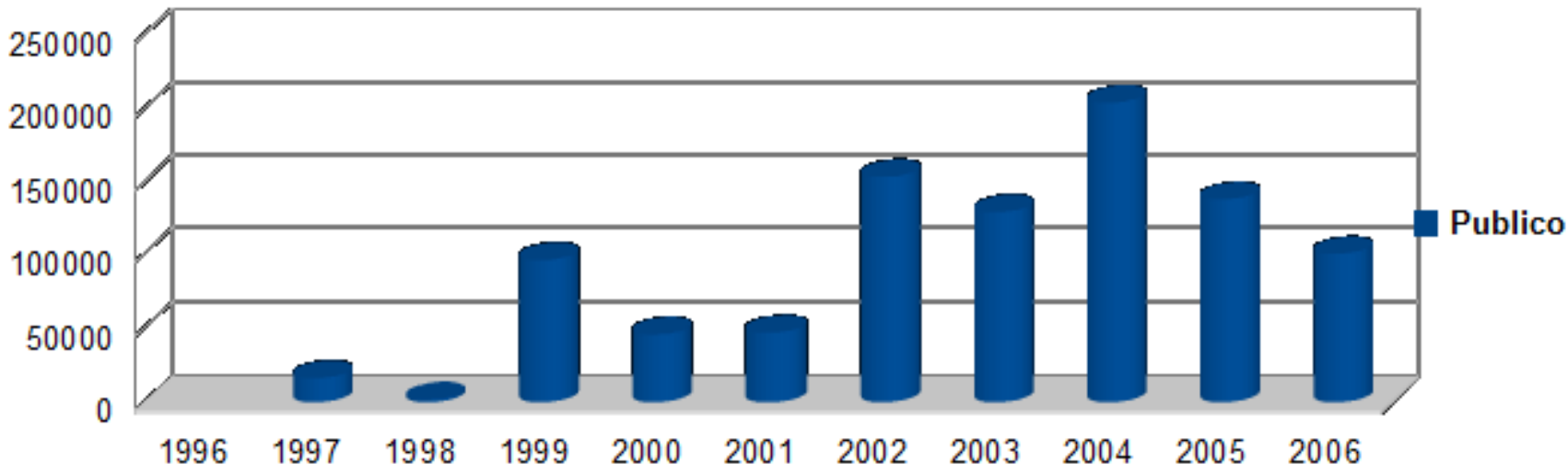

\begin{tabular}{|c|r|}
\hline \multicolumn{1}{|c|}{ Tipo } & \multicolumn{1}{c|}{ Püblico } \\
\hline Mofe Esportivo & 42998 \\
\hline Personalidades & 109747 \\
\hline Aprofundamento Jemático & 188756 \\
\hline Personagem ou personagens & 251199 \\
\hline Mote especificamente Musical & 182920 \\
\hline Questres sociais e ditadura & 155789 \\
\hline
\end{tabular}




\section{Documentário por temática}

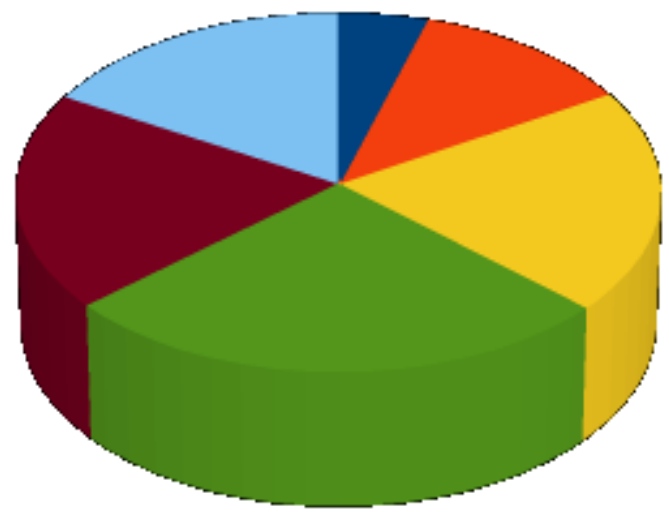

- Mote Esportivo

Personalidades

- Aprofundamento Temático

- Personagem ou personagens

Mote especificamente Musical

Questões so ciais e ditadura

\section{Documentários por temática excluindo as 5 maiores bilheterias.}

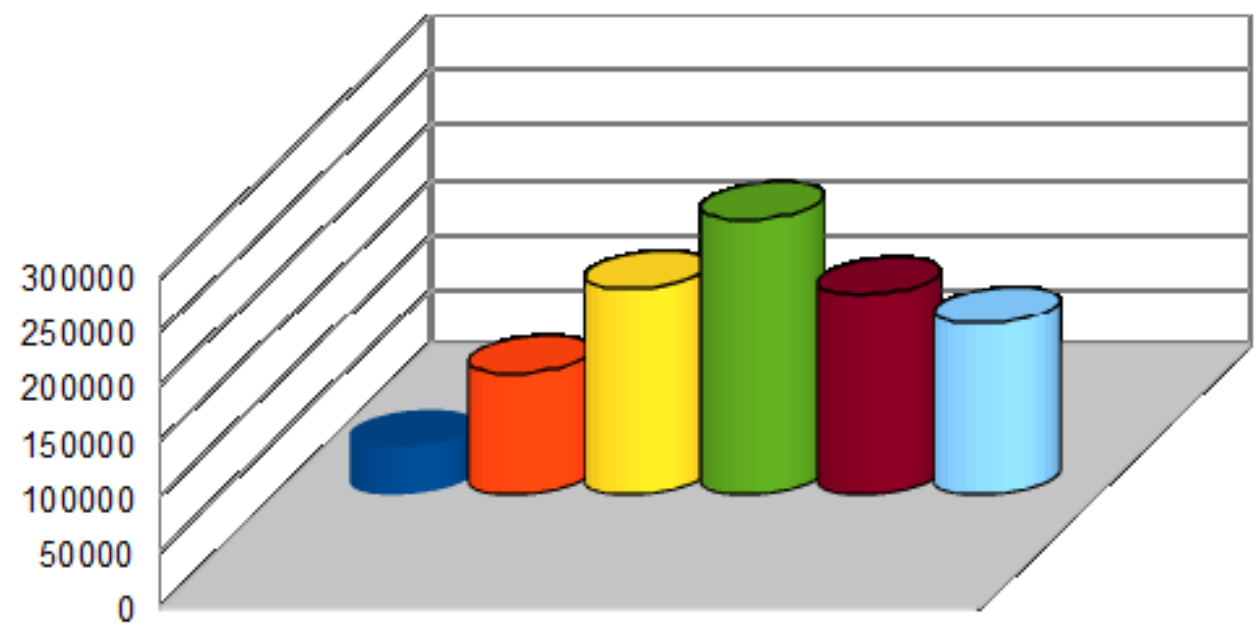

Mote Esportivo

$\square$ Personalidades

$\square$ Aprofundamento Temático

$\square$ Personagem ou perso-

nagens

$\square$ Mote especificam ente Musical

$\square$ Questões sociais e ditadu-

ra

Público

Avaliando e comparando os números com e sem as cinco maiores bilheterias, podemos perceber já, numa primeira e superficial análise, que os "desenhos" se alteram completamente. Focando a atenção no tipo Mote Esportivo percebemos claramente esta mudança. Este passa de primeiro lugar em público, para último, se retirarmos as cinco maiores bilheterias. Uma conclusão que podemos tirar desta análise é que os grandes públicos são exceções presentes em cada uma das classificações. 
Evolução do público do documentário em cada ano (1996 a 2006)

\begin{tabular}{|c|c|}
\hline Ano & Público \\
\hline 1996 & 265017 \\
\hline 1997 & 16434 \\
\hline 1998 & 1910 \\
\hline 1999 & 96295 \\
\hline 2000 & 45922 \\
\hline 2001 & 47173 \\
\hline 2002 & 496208 \\
\hline 2003 & 130362 \\
\hline 2004 & 462236 \\
\hline 2005 & 410962 \\
\hline 2006 & 100475 \\
\hline
\end{tabular}

\section{Público do Documentário por Ano}

\section{$1996-2006$}

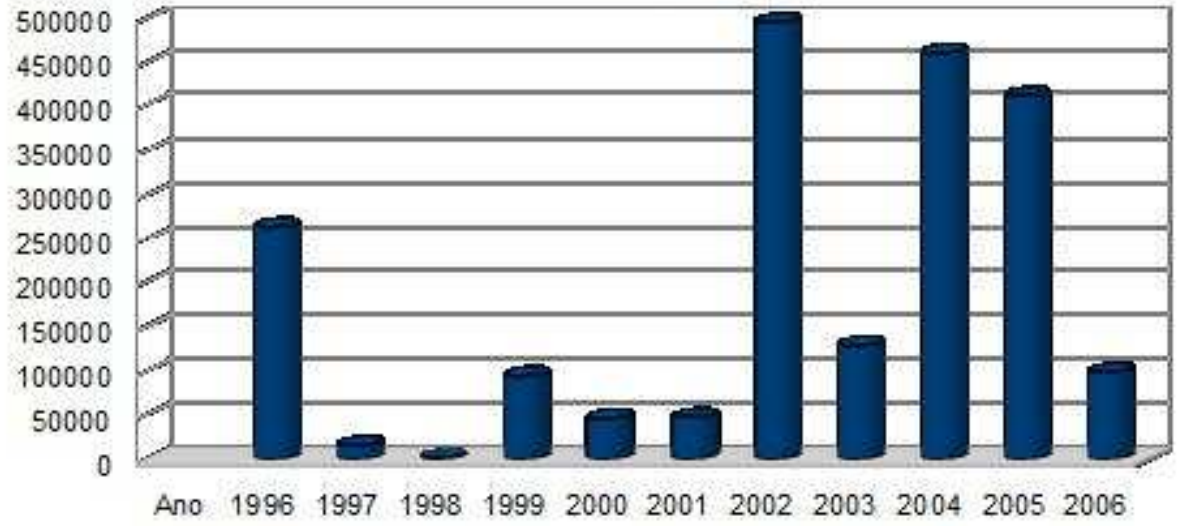

Coluna B

Podemos avaliar pelos gráficos que, embora 2004 tenha sido o ano com maior número de filmes lançados em circuito comercial, atingindo a marca de 16 lançamentos, percebemos que foi em 2002 que observamos maior público, mesmo tendo ocorrido apenas dez lançamentos em cinemas comerciais.

Percebe-se que a evolução de público segue um ritmo completamente irregular, onde, novamente, as exceções influem diretamente nos resultados do setor.

Número de filmes específicos de cada categoria lançados anualmente

\begin{tabular}{|c|c|c|c|c|c|c|c|}
\hline & $\begin{array}{c}\text { A profundamento } \\
\text { Temático }\end{array}$ & $\begin{array}{c}\text { Mote } \\
\text { es pecificamente } \\
\text { Musical }\end{array}$ & Mote Esportivo & $\begin{array}{c}\text { Per sonagem ou } \\
\text { personagens }\end{array}$ & Per son alidade s & $\begin{array}{l}\text { Questões } \\
\text { sociais }\end{array}$ & total \\
\hline 1996 & - & - & 1 & - & - & - & 1 \\
\hline 1997 & - & - & - & - & 2 & - & 2 \\
\hline 1998 & 1 & - & $=$ & - & - & - & 1 \\
\hline 1999 & 2 & - & 1 & 1 & - & - & 4 \\
\hline 2000 & 1 & 2 & - & 1 & 1 & 1 & 6 \\
\hline 2001 & 2 & 1 & - & 1 & 1 & 2 & 7 \\
\hline 2002 & 2 & 1 & 1 & 2 & 3 & 1 & 10 \\
\hline 2003 & 1 & 3 & 1 & - & - & - & 5 \\
\hline 2004 & 3 & 1 & 2 & 3 & 4 & 3 & 16 \\
\hline 2005 & 3 & 3 & 1 & 4 & 2 & 2 & 15 \\
\hline 2006 & 3 & 2 & 3 & 2 & 4 & 5 & 19 \\
\hline TOTAL & 18 & 13 & 10 & 14 & 17 & 14 & 86 \\
\hline
\end{tabular}


Pode-se concluir que o tipo Mote Esportivo, embora detentor do maior público e de três das cinco maiores bilheterias do setor, ocupa o último lugar entre os lançamentos. Isto demonstra, mais uma vez, que valores comerciais não estão entre os referenciais que incentivam novas produções.

\section{Tabela de freqüiência de diretores por filme}

\begin{tabular}{|c|c|c|c|c|}
\hline Nome & Ano & Tipo de documentário & Pủblico & Diretores \\
\hline Hist órias do Flamengo & 1999 & Mote Esportivo & 11157 & Alexandre Niemeyer \\
\hline Um Certo Dorival Caymmi & 2000 & Mote especificamente Musical & 2076 & Aluisio Didier \\
\hline Fown-in Surfing & 2906 & Mote Esportivo & 2398 & Alvaro Otero, Jorge Guimaräes e Rosaldo Cavalcanti \\
\hline Viva Säo Joäo & 2002 & Mote especificamente Musical & 7092 & Andrucha Waddington \\
\hline Pelé Etemo & 2004 & Mote Esportivo & 257932 & Anibal Massaini \\
\hline Rio de Jano: & 2004 & Personalidades & 8284 & Anna Azevedo, Eduardo Souza Lima e Renata Baldi \\
\hline Surf Adventures & 2002 & Mote Esportivo & 200853 & Arthur Fontes \\
\hline Q Cineasta da Selva. & 1997 & Personalidades & 4560 & Aurel io Michiles \\
\hline O Dia em que o Brasilesteve aqui & 2006 & Questốes so ciais e ditadura & 778 & Caito Ortiz e Joao Dornelas \\
\hline Preto e Branco & 2005 & Questóes sociais e ditadura & 177 & Carlos Nader: \\
\hline Morro da Conceição & 2005 & Personagem ou personagens & 4943 & Cristiana Grumbach \\
\hline Família Alcântara & 2006 & Questões sociais e ditadura & 307 & Daniel Sola Santiago e Lilian Sola Santiago \\
\hline 2000 Nordestes & 2001 & Aprofund amento Temático & 4297 & David Franca Mendes \\
\hline Sou Feia mas Tó na Moda & 2005 & Mote especificamente Musical & 5575 & Denise Garcia \\
\hline Ferra do Mar & 2000 & Aprofund amento Temático & 1531 & Eduardo Caron e Mir ella Martinelfi \\
\hline O Fim e o Principio & 2005 & Personagem ou personagens & 9674 & Eduardo Coutin ho \\
\hline Santo Forte & 1999 & Personagem ou personagens & 18313 & Eduardo Coutin ho \\
\hline Peões & 2004 & Personagem ou personagens & 17960 & Eduardo Coutin ho \\
\hline Babillónia 2000 & 2000 & Personagem ou personagens & 15301 & Ed uardo Coutin ho \\
\hline Edificio Master & 2002 & Personagem ou personagens & 86483 & Eduardo Coutin ho \\
\hline Vocação do Poder & 2005 & Personagem ou personagens & 1995 & Eduardo Escorel e Jose Joffily \\
\hline Zieo & 2003 & Mote Esportivo & 1000 & Eliseu Evald \\
\hline Nelson Goncalves & 2001 & Mote especificamente Musical & 4381 & Elizen Evald \\
\hline Senta a Pua & 2001 & Aprofund amento Temático & 13181 & Erik de Castro \\
\hline Dom Helder Câmara & 2006 & Personalidades & 3592 & Erika Bauer \\
\hline Rocha que Voa & 2002 & Personalidades & 5929 & Eryk Rocha \\
\hline Amazónia & 2005 & Aprofund amento Temático & 135 & Eval do Mocarzel \\
\hline A Margem da Imagem & 2004 & Questões so ciais e ditadura & 1728 & Eval do Mocarzel \\
\hline Do Luto a Luta & 2006 & Aprofund amento Temático & 3107 & Eval do Mocarzel \\
\hline A Mochila do Mascate & 2006 & Personalidades & 2191 & Gabriela Greeb \\
\hline Fala Tu & 2004 & Personagem ou personagens & 10526 & Guitherme Coeltho \\
\hline Ginga: a aima do futebol brastileiro & 2006 & Mote Esportivo & 1266 & Hank Levine, Marcelo Machado e Tocha Alves \\
\hline Paulinito da Viola & 2003 & Mote especificamente Musical & 54025 & Izabel Jaguaribe \\
\hline Mado & 2005 & Personalidades & 3283 & Joäo Batista de Andrade \\
\hline Janela da A lma: & 2002 & Aprofund amento Temático & 141360 & João Jardim e Walter Carval ho \\
\hline Entreatos & 2004 & Personalidades & 38341 & Joäo Moreira Salks \\
\hline Nelson Fraire & 2003 & Mote especificamente Musical & 64264 & Joäo Moreira Salles \\
\hline Samba Riachäo & 2004 & Mote especificamente Musical & 1330 & Jorge Alfredo \\
\hline O Charnado de Deus & 2001 & Personagem ou personagens & 4535 & Jose Joffily \\
\hline Ônibus 174 & 2902 & Questões sociais e ditadura & 35290 & José Padilha \\
\hline 33. & 2004 & Personagem ou personagens & 11500 & K iko Goifman \\
\hline O Cárcere e a Rúa & 2005 & Questöes so ciais e ditadura & 7792 & Liviana Sulzbach \\
\hline
\end{tabular}




\begin{tabular}{|c|c|c|c|c|}
\hline Timor & 2002 & Aprofund amen to Temático & 7683 & Lucélia S antos \\
\hline Olhar Estrangeiro & 2006 & Aprofund amen to Temático & 4277 & Lucia Murat \\
\hline Anésia-Um Vôo no Tempo & 2001 & Personalidades & 1498 & Ludmila Ferolla \\
\hline Pierre Verger & 2000 & Personalidades & 3400 & Lula Buarque de $\mathrm{H}$ olanda \\
\hline Doutores da A legria & 2005 & Aprofund amen to Temático & 26294 & Mara Mourão \\
\hline Zé Pureza & 2006 & Questões so ciais e ditadura & 415 & Marcelo Ernandez \\
\hline $\begin{array}{l}\text { Nós que Aqui Estamos por Vós } \\
\text { Esperamos }\end{array}$ & 1999 & Aprofund amen to Temático & 58577 & Marcelo Mazagao \\
\hline Nem Gravata nem H on ra & 2002 & Personagem ou personagens & 3237 & Marcelo Mazagäo \\
\hline Estamira & 2006 & Personagem ou personagens & 38052 & Marcos Prado \\
\hline $\begin{array}{l}\text { Carnaval, Bexiga, Funk e } \\
\text { Sombrinha }\end{array}$ & 2006 & Mote especificamente Musical & 6955 & Marcus Vinicius F austini \\
\hline Justiça & 2004 & Questões sociais e ditadura & 28635 & Maria Augusta Ramos \\
\hline Vinícius & 2005 & Personalidades & 271979 & Miguel Faria Jr \\
\hline Moro no Brasil & 2005 & Mote especificamente Musical & 2680 & Mika Kau rismaki \\
\hline Extremo Sul & 2005 & Mote Esportivo & 13571 & Mon ica Schmiedt, Sylvestre Campe \\
\hline Todos os Corações do Mundo & 1996 & Mote Esportivo & 265017 & Murilo Sal les \\
\hline O Homem pode Voar & 2006 & Personalidades & 1912 & Nelson Hoineff \\
\hline Raízes do Brasil & 2004 & Aprofund amen to Temático & 19420 & Nelson Pereira dos Santos \\
\hline Nizinga & 2006 & Mote especificamente Musical & 21 & Octavio Bezerra \\
\hline O Rap do Pequeno Príncipe & 2000 & Questões sociais e ditadura & 22577 & Paulo Caldas e Marcelo Luna \\
\hline Bahia de Todos os Sambas & 2000 & Mote especificamente Musical & 1037 & Paulo Cesar Saraceni e Leon Hirszman \\
\hline Banda de Ipanema & 2003 & Mote especificamente Musical & 2004 & Paulo Cesar Saraceni \\
\hline Evandro Teixeira - In stantâneos & 2004 & Personalidades & 875 & Paulo Fontenelle \\
\hline O prisioneiro da Grade de Ferro & 2004 & Questões so ciais e ditadura & 27848 & Paulo Sacramento \\
\hline Poeta das Sete Faces & 2002 & Personalidades & 4495 & Paulo Thiago \\
\hline Coisa Mais Linda & 2005 & Mote especificamente Musical & 35861 & Paulo Thiago \\
\hline Fábio Fabulo so & 2004 & Mote Esportivo & 12458 & Pedro Cezar, Ricardo Bocao, Antonio Ricardo \\
\hline Um Craque Chamado Divino & 2006 & Mote Esportivo & 1148 & Penna Filho \\
\hline Fé & 1999 & Aprofund amento Temático & 8248 & Ricardo Dias \\
\hline A Pessoaé para o que Nasce & 2005 & Personagem ou personagens & 24475 & Roberto Berliner \\
\hline Tudo é Brasil & 1998 & Aprofund amento Temático & 1910 & Rogerio Sganzerla \\
\hline Um passaporte Húngaro & 2003 & Aprofund amento Temático & 9069 & Sandra Kogut \\
\hline Meninas & 2006 & Personagem ou personagens & 4208 & Sandra Werneck \\
\hline Onde a Terra Acaba & 2002 & Personalidades & 3786 & Sergio Machado \\
\hline Soldado de Deus & 2005 & Aprofund amento Temático & 2528 & Sérgio Sanz \\
\hline Glauber o Filme & 2004 & Personalidades & 13456 & Silvio Tendler \\
\hline $\begin{array}{l}\text { O Sol-Caminhando Contra o } \\
\text { Vento }\end{array}$ & 2006 & Questões sociais e ditadura & 9401 & Tete Moraes \\
\hline O Sonho de Rose & 2001 & Questões sociais e ditadura & 12232 & Tete Moraes \\
\hline O Velho-História de L.C.Prestes & 1997 & Personalidades & 11874 & Toni Venturi \\
\hline Dia de Festa & 2006 & Questões sociais e ditadura & 1620 & Toni Venturi \\
\hline Soy Cuba-O Mamute Siberiano & 2006 & Aprofund amento Temático & 16556 & Vicente Ferraz \\
\hline Língua - Vidas em Português & 2004 & Aprofund amen to Temático & 11943 & Victor Lopes \\
\hline Barra 68 & 2001 & Questões so ciais e ditadura & 6989 & Vladimir Carvalho \\
\hline Moacir Arte Bruta & 2006 & Personalidades & 2271 & Walter Cavalho \\
\hline
\end{tabular}

Podemos concluir que a freqüência de diretores por temática varia, pois existem poucos diretores que se dedicam apenas ao documentário. Um bom exemplo de um diretor que se dedica apenas ao documentário é Eduardo Coutinho, que além de realizar filmes lançados quase que anualmente, se mantêm sempre no modo de documentário de personagem.

\section{Conclusão}

$\mathrm{Na}$ análise de público por temática podemos avaliar que, nessas categorias, há poucos filmes arrecadando 
muito público e muitos filmes arrecadando pouco público, o que acaba colocando alguns grupos como detentores de público, mas na realidade isso é conseqüência de dois ou três filmes.

O número de lançamentos por temática não tem relação com o público. Em alguns casos há filmes de uma determinada temática com muitos lançamentos e públicos pequenos. Os filmes com maiores bilheterias, de alguma forma dialogam com elementos da cultura brasileira, como o futebol, o surf e a música. Os cinco filmes com maior bilheteria são relacionados a isso, mesmo que Vinicius tenha sido enquadrado em documentário de personalidade, este fica também relacionado à categoria mote musical. Talvez o público tenha um interesse maior por filmes com temáticas ou pessoas conhecidas.

Eduardo Coutinho é um dos únicos diretores exclusivos do documentário. Além disso, é autor de filmes genuinamente autorais e enquadrados dentro do modelo de documentário de personagem. Eles também são lançados com uma freqüência regular e têm público cativo que varia entre 15 e 18 mil espectadores, com exceção de Edifício Master que fez 86 mil. Pode-se concluir que, embora a produção de documentários esteja aumentando, seu público não tem acompanhado esta tendência de uma forma equilibrada.

\section{Anexo}

\section{Documentários exibidos em circuito comercial entre os anos 1996 - 2006 cronologicamente}

\begin{tabular}{|c|c|c|}
\hline Nome & Ano & Diretores \\
\hline Todos os Coraçöes do Mundo & 1996 & Murilo Salles \\
\hline O Cineasta da Selva & 1997 & Aurelio Michiles \\
\hline O Velho - História de L.C. Prestes & 1997 & Toni Venturi \\
\hline Tudo é Brasil & 1998 & Rogerio Sganzerla \\
\hline Fé & 1999 & Ricardo Dias \\
\hline $\begin{array}{l}\text { Nós que Aqui Estamos por Vós } \\
\text { Es peramos }\end{array}$ & 1999 & Marcelo Mazagao \\
\hline His tórias do Flamengo & 1999 & Alexandre Niemeyer \\
\hline Santo Forte & 1999 & Eduardo Coutinho \\
\hline Pierre Verger & 2000 & Lula Buarque deHolanda \\
\hline Bahia de Todos os Sambas & 2000 & Paulo Cesar Saraceni e Leon Hirs zman \\
\hline Babilônia 2000 & 2000 & Eduardo Coutinho \\
\hline UmCerto Dorival Caymmi & 2000 & Aluis io Didier \\
\hline O Rap do Pequeno Príncipe & 2000 & Paulo Caldas e Marcelo Luna \\
\hline Terra do Mar & 2000 & Eduardo Caron e Mirella Martinelli \\
\hline$\overline{\text { Senta a Pua }}$ & 2001 & Erik de Castro \\
\hline O Sonho de Rose & 2001 & Tete Moraes \\
\hline Nelson Gonçalves & 2001 & Elizeu Ewald \\
\hline Barra 68 & 2001 & Vladimir Carvalho \\
\hline O Chamado de Deus & 2001 & Jose Joffily \\
\hline 2000 Nordestes & 2001 & David Franca Mendes \\
\hline Anésia-Um Vồo no Tempo & 2001 & Ludmila Ferolla \\
\hline Poeta das Sete Faces & 2002 & Paulo Thiago \\
\hline Onde a Terra Acaba & 2002 & Sergio Machado \\
\hline Surf Adventures & 2002 & Arthur Fontes \\
\hline Viva Săo João & 2002 & Andrucha Waddington \\
\hline Edificio Master & 2002 & Eduardo Coutinho \\
\hline Rocha que Voa & 2002 & Eryk Rocha \\
\hline Nem Gravata nem Honra & 2002 & Marcelo Mazagão \\
\hline Ōnibus 174 & 2002 & José Padilha \\
\hline Timor & 2002 & Lucélia Santos \\
\hline Janela daAlma & 2002 & João Jardim e Walter Carvalho \\
\hline Nelson Freire & 2003 & João Moreira Salles \\
\hline Banda de Ipanema & 2003 & Paulo Cesar Saracini \\
\hline Paulinho da Viola & 2003 & Izabel Jaguaribe \\
\hline Zico & 2003 & Eliseu Ewald \\
\hline Um passaporte Húngaro & 2003 & Sandra Kogut \\
\hline Motoboys - Vida Loca & 2004 & Caito Ortiz \\
\hline Peões & 2004 & Eduardo Coutinho \\
\hline Entreatos & 2004 & João Moreira Salles \\
\hline A Margem da Imagem & 2004 & Evaldo Mocarzel \\
\hline 33 & 2004 & Kiko Goifman \\
\hline Justiça & 2004 & Maria Augusta Ramos \\
\hline
\end{tabular}




\section{Bibliografia:}

BERNARDET, Jean-Claude. Cineastas e Imagens do povo. São Paulo: Editora Cia. das Letras, 2003.

DA-RIN, Sílvio. Espelho partido. Rio de Janeiro: Azougue Editorial, 2006.

GOMES, Paulo Emílio Sales. Cinema: trajetória do subdesenvolvimento. São Paulo: Paz e Terra, 1996.

GATTI, André Piero. Distribuição e exibição na indústria cinematográfica brasileira (1993 - 2003). Tese (Doutorado em Multimeios) - Instituto de Artes, Unicamp, Campinas. 2005.

LABAKI, Amir. Introdução ao documentário brasileiro. São Paulo: Editora Francis, 2006.

LABAKI, Amir. É tudo verdade - reflexões sobre a cultura do documentário. São Paulo: Francis, 2005.

LINS, Consuelo. O documentário de Eduardo Coutinho - televisão, cinema e vídeo. Rio de Janeiro: Jorge Zahar Ed, 2007.

LINS, Consuelo e MESQUITA, Cláudia. Filmar o Real. Rio de Janeiro: Jorge Zahar Ed, 2008.

MELEIRO, Alessandra. Coleção cinema no mundo - Indústria, política e mercado - vol. III América Latina. São Paulo: Escrituras Editora, 2007.

MENDONCA, Leandro. O documentário e a ocupação preguiçosa do mercado. In: MACHADO, Rubens Jr., SOARES, Rosana de Lima, ARAUJO, Luciana Correia (orgs.). Estudos de cinema SOCINE. São Paulo: Annablume, Socine, 2007. Cap. 02, p. 247 - 255.

MOURAO, Maria Dora e LABAKI, Amir. (orgs.) O cinema do real. São Paulo: Cosac e Naife 2005.

NAGIB, Lusia. O cinema da retomada - depoimentos de 90 cineastas dos anos 90. São Paulo: Ed.34, 2002.

NICHOLS, Bill. Introdução ao documentário. Campinas: Editora Papirus, 2005.

RAMOS, Fernão Pessoa (org.). Teoria contemporânea do cinema - Documentário e Narratividade Ficcional. São Paulo: Editora Senac, 2005.

RAMOS, Fernão Pessoa. Mas afinal ... o que é mesmo documentário. São Paulo: Editora Senac, 2008.

RAMOS, Fernão Pessoa. O que É documentário? Estudos de Cinema 2000 SOCINE. Porto Alegre: Sulinas, 2001. Também http://www.bocc.ubi.pt/pag/pessoa-fernao-ramos-o-que-documentario.pdf

SALLES, João Moreira. A dificuldade do documentário. In: MARTINS, José de Souza, ECKERT, Cornélia e NOVAES, Sylvia Cainby. O Imaginário e o poético nas ciências sociais. São Paulo: Edusc, 2005. Cap. 03, p. $57-71$.

SIMIS, Anita. Estado e Cinema no Brasil. São Paulo: Annablume; FAPESP; Itaú Cultural, 2008. 
STAM Robert. Introdução à teoria do Cinema. Campinas SP: Papirus, 2003.

TEIXEIRA, Francisco Elinaldo (org). Documentário no Brasil - Tradição e transformação. São Paulo: Summus, 2004.

XAVIER, Ismail. Cinema brasileiro moderno. São Paulo: Paz e Terra, 2001.

\section{Notas:}

(1) LABAKI, Amir Rumo a uma economia do documentário brasileiro http://www.itsalltrue.com.br/periodico/coluna/coluna.asp?lng=\&id=138. Acessado em 05/06/2008.

(2) LINS, Consuelo e MESQUITA, Cláudia. Filmar o Real. Rio de Janeiro: Jorge Zahar Ed, 2008, p. 12.

(3) Entre os anos de 1995 e o fim de 2002, o numero de salas no Brasil passou de cerca de mil para perto de 1.700 - sendo que, segundo dados da Abrasce (Associação de Shoping Centers), mil salas estão localizadas nos centros comerciais (ou seja 65\% do total). GATTI, Andre Piero. "Distribuição e Exibição na Indústria Cinematográfica Brasileira" p. 266 Apud Almeida, P.S. Butcher, P, Cinema $e$ desenvolvimento, p.64.

(4) Uma das exceções na televisão aberta nacional que exibe documentários é a TV Cultura que, em parceria com o Ministério da Cultura, produz o DOC $\mathrm{TV}$, um programa de fomento à produção independente que proporciona, além de verba para a realização, uma janela para a exibição. Outros canais públicos, o Canal Brasil e outros canais a cabo, como o GNT, também direcionam parte de sua grade para o formato documentário.

(5) Filme b (http://www.filmeb.com.br)

\section{Mini Currículo :}

Mestranda no curso de pós-graduação em multimeios da Universidade Estadual de Campinas (UNICAMP), com graduação em realização audiovisual pela Universidade do Vale do Rio dos Sinos (UNISINOS/RS) e atua na área de direção de documentários. email: tnoll @ hotmail.com 